\title{
奨励賞
}

\section{ITL-004 触覚による物体認識の脳内ネットワーク}

\author{
講演者: 北田亮 (自然科学研究機構 生理学研究所) \\ 司会者:月浦崇 (京都大学)
}

私たちは見るだけでなく，触るだけでも周りの物体を認識することができます。では脳はどのように 触覚入力を解釈して, 物体を認識するのでしょうか? これまで多くの認知神経科学的研究が視覚による 物体認知の脳内ネットワークについて明らかにしてきました。しかし視覚と比べると触覚の研究は少な く，その脳内ネットワークについてはよく分かっていないのが現状です。私はこれまで心理物理学的手 法と機能的磁気共鳴画像法 (fMRI) を活用して, 触覚による物体の認識に関する脳内メカニズムを調べ てきました。本講演では主要な研究成果を 3 点紹介します。まず物体の認識には粗さや形といった物体 の属性を知覚する必要があります。私たちはこれらの属性のうち, 粗さのような素材的属性と方位のよ うな空間的属性は脳内で分散的に処理される可能性を示しました。次に分散処理された属性は統合され て物体の認識に至ると考えられますが, 私たちはこの過程において, 専ら視覚に関わるとされていた大 脳の腹側視覚経路が関与する可能性を明らかにしました。最後に早期失明者を対象にした研究から, 腹 側視覚経路は視覚経験に関係なく触覚による物体の認識に関与することを示しました。これらの成果は, 触覚による物体認識には古典的な感覚野 (体性感覚野) だけでなく, 視覚野も含む広範な脳部位の協調 作業が重要であることを示しています。 